\title{
EGPA Associated to chCRR A Case Report Eosinophilic Granulomatosis with Polyangiitis Associated to Chromophobe Renal Cell Carcinoma: A Case Report
}

Sandra Maximiano de Oliveira ${ }^{1^{*}}$, Cezar Kozak Simaan ${ }^{2}$, Leopoldo Luiz dos Santos Neto ${ }^{3}$, Cleandro Pires de Albuquerque ${ }^{1}$, Isadora Jochims ${ }^{4}$, Ana Paula Monteiro Gomides Reis ${ }^{2}$, Francisco Aires Côrrea Lima ${ }^{1}$, Daniel de Amorim Rondon ${ }^{1}$, Ana Carolina Emy Vicente Hidaka ${ }^{1}$, Ana Paula Faria Carvalho ${ }^{1}$, Talita Yokoy de Souza ${ }^{1}$ and Luciano Junqueira Guimarães ${ }^{1}$

${ }^{1}$ Rheumatology Department, Brasilia University Hospital, Brazil

${ }^{2}$ Department of Rheumatology, Brasilia University, Brazil

${ }^{3}$ Department of Internal Medicine, Brasilia University, Brazil

${ }^{4}$ Brazilian Rheumatology Society, Brazil

*Corresponding author: Sandra Maximiano de Oliveira, Rheumatology Department, Brasília University Hospital, Federal District, Brazil, Tel: +5561991776559; E-mail: sandramaximianoo@gmail.com

Received date: Mar 13, 2017; Accepted date: Mar 23, 2017; Published date: Apr 3, 2017

Copyright: (c) 2017 Maximiano de Oliveira S. This is an open-access article distributed under the terms of the Creative Commons Attribution License, which permits unrestricted use, distribution, and reproduction in any medium, provided the original author and source are credited.

\section{Case Report}

Paraneoplastic syndromes are characterized by the set of signs and symptoms of an underlying cancer, frequently occult, due to a variety of remote tumor effects unrelated to the mechanical impact of the tumor mass or distant metastasis [1,2]. Among these syndromes, paraneoplastic vasculitis are very rare, especially necrotizing systemic vasculitis. It is estimated that $2-5 \%$ of all causes of vasculitis are paraneoplastic, with the most common presentation being leukocitoclastic cutaneous vasculitis related to hematological malignancies $[1,3,4]$, and fewer cases related to solid organ tumors as an underlying cause.

There are some reports of paraneoplastic ANCA-associated vasculitis (AAV), especially granulomatosis with polyangiitis associated with hematological malignancies and with solid organ tumors such as lung and renal carcinomas [5]. We report a case of eosinophilic granulomatosis with polyangiitis (EGPA) associated to chromophobe renal cell carcinoma (chCRR), an unusual form of malignant renal neoplasm, with complete remission of vasculitis after tumor resection.

It is important to be aware of the rare association between vasculitis and cancer, since early recognition could provide proper treatment and better prognosis. A 62 year-old man presented with painful palpable purpura on lower limbs and palms, dry cough, dyspnea and fever four weeks prior to admission. He had a long medical history of hypertension and diabetes, and lifetime tobacco exposure of 35 packyears.

There was also a severe persistent asthma starting three years before. Weight loss, abdominal pain and urinary symptoms were absent. On physical examination, there were skin lesions (Figure 1), wheezing on chest auscultation and a body mass index of $27.2 \mathrm{~kg} / \mathrm{m}^{2}$. Laboratory tests showed marked eosinophilia $\left(5,700 \mathrm{cells} / \mathrm{mm}^{3}\right.$ at admission, peaking 15,520 cells $/ \mathrm{mm}^{3}$ during hospital stay), elevated erythrocyte sedimentation rate $(80 \mathrm{~mm} / \mathrm{h})$ and C-reactive protein $(2,6 \mathrm{mg} / \mathrm{dL}, \mathrm{NR}$ $<0,5 \mathrm{mg} / \mathrm{dL}$ ). Renal function and urine analysis were normal. Skin biopsy demonstrated eosinophilic leukocitoclastic vasculitis of small vessels with fibrinoid necrosis and eosinophilic perivascular infiltrates (Figure 2).

Antinuclear antibody and antineutrophil cytoplasmic antibodies (ANCA) tested negative. Serological tests for hepatitis B and C viruses and acquired human immunodeficiency virus were negative. At admission, chest radiography revealed pulmonary infiltrates.

A computerized tomography (CT) scan was performed, showing bilateral alveolar infiltrates and a small indeterminate solid nodule on left lower lobe. Daily oral prednisone was started (up to $1 \mathrm{mg} / \mathrm{kg}$ ) with no improvement. The patient evolved with respiratory insufficiency, with severe hypoxemia, and then intravenous (IV) methylprednisolone $1 \mathrm{~g} /$ day was prescribed for three days.

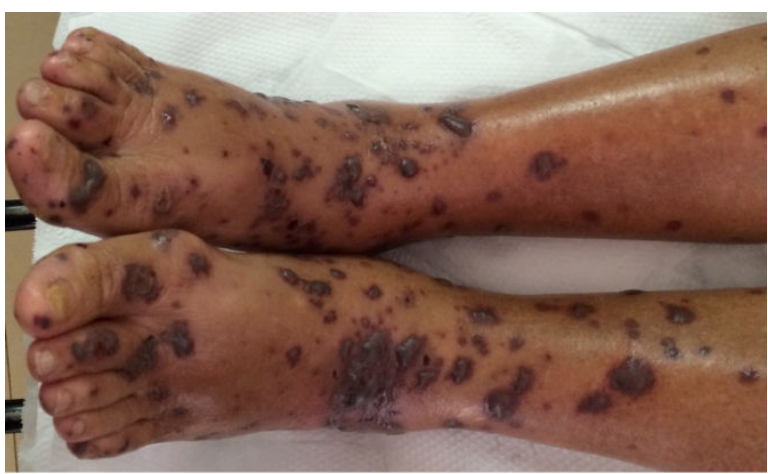

Figure 1: Skin lesions-Multiple rounded and confluent palpable purpura and tense blisters on lower limbs.

There was a striking improvement, with normalization of eosinophil count and complete resolution of respiratory symptoms. However, the cutaneous vasculitis not only persisted, but also progressed some days after the IV glucocorticoid therapy, with new skin lesions and ulceration of older ones. An abdominal CT revealed a mass of $5 \mathrm{~cm}$ diameter on upper right kidney pole, with enhancement after the injection of contrast agent. Three months later, the patient went through laparoscopic radical right nephrectomy, and histopathology revealed a chromophobe renal cell carcinoma. Right after the resection of the tumor, there was a complete remission of the vasculitis, with progressive resolution of skin lesions. The patient had no recurrences 18 months after surgical procedure. 
Citation: Maximiano de Oliveira S, Simaan CK, dos Santos Neto DS, de Albuquerque CP, Jochims I, et al. (2017) EGPA Associated to chCRR A Case Report Eosinophilic Granulomatosis with Polyangiitis Associated to Chromophobe Renal Cell Carcinoma: A Case Report. J Vasc 3: 121. doi:10.4172/2471-9544.1000121

Page 2 of 3

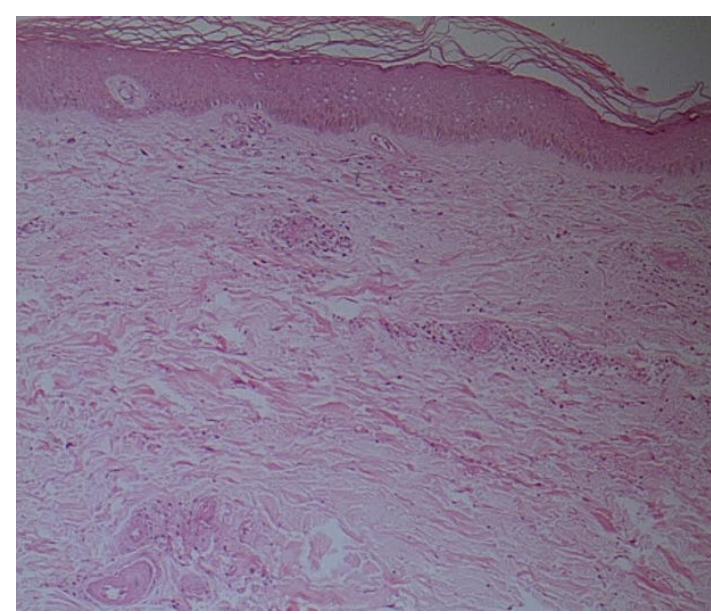

Figure 2: Skin biopsy-Leukocitoclastic vasculitis with fibrinoid necrosis and perivascular eosinophilic infiltrate.

\section{Discussion}

EGPA is the less frequent of AAV, a group of chronic inflammatory pauci-imunne disorders that involve small vessels [6-8]. The 2012 revised International Chapel Hill Consensus Conference Nomenclature of Vasculitides defines it as an eosinophil-rich and necrotizing granulomatous inflammation, often involving the respiratory tract, and necrotizing vasculitis predominantly affecting small to medium vessels, associated with asthma and eosinophilia [9].

The patient here described presented asthma, eosinophilia, fleeting pulmonary infiltrates and eosinophilic tissue infiltrates, fulfilling the 1990 American College of Rheumatology classification criteria for EGPA, with no neuropathy, paranasal sinus abnormalities or glomerulonephritis [10]. ANCA, which is found in about $40 \%$ of EGPA patients, more frequently when glomerulonephritis is present [6], was negative.

Concomitant with EGPA, the patient was diagnosed with a chromophobe renal cell carcinoma, and there was a complete remission of vasculitis after tumor resection. Hence, the vasculitis was associated with a probable specific etiology, and in this case, it could eventually be named, according to the 2012 revised International Chapel Hill Consensus Conference Nomenclature of Vasculitides, a cancer-associated EGPA [9]. Rheumatic diseases may be associated to neoplastic conditions. Some rheumatic diseases are associated to an increased risk of developing cancer, for example non-Hodgkin lymphoma in Sjögren's syndrome and rheumatoid arthritis, and some rheumatic diseases or syndromes may be paraneoplastic, such as the classical association between dermatomyositis and cancer [11,12]. A range of autoimmune phenomena may occur related to malignancy. Regardless the pathogenesis is still unclear, some mechanisms have already been proposed to elucidate this connection, as the release of cytokines and antigens by malignant cells $[1,3]$. These phenomena are better described on hematological cancers, although a relation with solid tumors, like prostate and ovarian cancers, has already been found $[9,13,14]$. Leukocitoclastic vasculitis, polyneuritis and autoimmune hemolytic anemia seem to be the most frequent autoimmune epiphenomena related to malignancies $[9,13,14]$.
Nevertheless, the relation between vasculitis and cancer is rare, and the occurrence of systemic vasculitis is exceptional. Cancers are found on $5 \%$ of patients with vasculitis [4], and the most common form is leukocitoclastic cutaneous vasculitis [3,14,15], with strongest association to hematological disorders, lung, bowel and renal cancers $[4,13,14]$. Concerning AAV, the association with cancer is rare, and most cases described are granulomatosis with polyangiitis $[1,5,11]$.

There are very few cases of EGPA as a paraneoplastic syndrome reported in medical literature. EGPA, a rare systemic vasculitis, has been described in association to hematological malignancies (leukemia and lymphoma) [16,17], breast cancer [18], melanoma [19,20], thymic neuroendocrine tumor [21] and lung cancer [22]. To our knowledge, this is the first case report of EGPA as a paraneoplastic manifestation of renal cell carcinoma, with no articles retrieved in a PubMed search.

Chromophobe renal cell carcinoma (chRCC) is a rare renal neoplasm, accounting for $5 \%$ of renal tumors [23-25]. It affects men twice more often than women, more commonly between sixth and eighth decades of life. Smoke, obesity and hypertension are wellestablished risk factors. [23]. Only $6-10 \%$ of the patients will present abdominal pain, palpable mass and hematuria, being most of these tumors asymptomatic and found incidentally on radiographic exams [23]. On radiographic exams, chRCC appears as a well-defined and homogeneous mass, scarcely invading perinephric tissue or blood vessels [24]. Usually, patients are diagnosed in early stages (T1 or T2), being frequently cured surgically, with good prognosis [24-26]. All these clinical and epidemiological features were found in the patient here described.

Paraneoplastic syndromes are very rare in chRCC. There is one case reported of linear IgA bullous dermatosis [27], and no other reports were found on a PubMed search. However, some cases of peripheral eosinophilia were reported and the recurrence of this abnormality after tumor resection seemed to be related to poor prognosis, tumor recurrence and rapid disease progression [28].

In summary, rheumatic paraneoplastic syndromes are quite unusual, but they have been described in association with hematological and solid organ malignancies. Cancer-associated AAV are very rare, nevertheless medical community should be aware of this condition in order to establish early diagnosis and proper treatment, improving prognosis of these patients.

\section{References}

1. Azar L, Khasnis A (2013) Paraneoplastic rheumatologic syndromes. Curr Opin Rheumatol 25: 44-49.

2. Silva JA, Mesquita Kde C, Igreja AC, Lucas IC, Freitas AF, et al. (2013) Paraneoplastic cutaneous manifestations: concepts and updates. An Bras Dermatol 88: 9-22.

3. Loricera J, Calvo-Río V, Ortiz-Sanjuán F, González-López MA, Fernández-Llaca $\mathrm{H}$, et al. (2013) The spectrum of paraneoplastic cutaneous vasculitis in a defined population: incidence and clinical features. Medicine 92: 331-343.

4. Gulati S, Patel NP, Swierczynski SL (2012) Vasculitides associated with haematological malignancies: a case-based review. BMJ Case Rep 2012.

5. Lloyd M, de Verteuil J, Andrews PA (2002) Renal vasculitis associated with renal cell carcinoma. J R Soc Med 95: 305-306.

6. Greco A, Rizzo MI, De Virgilio A, Gallo A, Fusconi M, et al. (2015) Churg-Strauss syndrome. Autoimmun Rev 14: 341-348.

7. Puéchal X (2016) Immunotherapy in eosinophilic granulomatosis with polyangiitis: a new step forward? J Vasc 2: e106. 
Citation: Maximiano de Oliveira S, Simaan CK, dos Santos Neto DS, de Albuquerque CP, Jochims I, et al. (2017) EGPA Associated to chCRR A Case Report Eosinophilic Granulomatosis with Polyangiitis Associated to Chromophobe Renal Cell Carcinoma: A Case Report. J Vasc 3: 121. doi:10.4172/2471-9544.1000121

Page 3 of 3

8. Villacorta J, Díaz-Crespo F, Stanescu R, Fernandez-Juarez G (2016) Large and small vessel severe involvement in ANCA-associated vasculitis. J Vasc 2: e105.

9. Jennette JC, Falk RJ, Bacon PA, Basu N, Cid MC, et al. (2013) 2012 revised International Chapel Hill Consensus Conference Nomenclature of Vasculitides. Arthritis Rheum 65: 1-11.

10. Masi AT, Hunder GG, Lie JT, Michel BA, Bloch DA, et al. (1990) The American College of Rheumatology 1990 criteria for the classification of Churg-Strauss syndrome (allergic granulomatosis and angiitis). Arthritis Rheum 33: 1094-1100.

11. Hochberg MC (2015) Rheumatology (6th edn). Mosby Elsevier, Philadelphia.

12. Bellan M, Boggio E, Sola D, Gibbin A, Gualerzi A, et al. (2017) Association between rheumatic diseases and cancer: results from a clinical practice cohort study. Intern Emerg Med Epub ahead of print.

13. Nenova IS, Valcheva MY, Beleva EA, Tumbeva DY, Yaneva MP, et al. (2016) Autoimmune Phenomena in Patients with Solid Tumors. Folia Med (Plovdiv) 58: 195-199.

14. Ayob S, McDonagh AJ (2015) Paraneoplastic leucocytoclastic vasculitis heralding a solid-organ tumour. Clin Exp Dermatol 40: 206-208.

15. Curgunlu A, Karter Y, Uyanik O, Tunçkale A, Curgunlu S (2004) Leukocytoclastic vasculitis and renal cell carcinoma. Intern Med 43: 256-257.

16. Calonje JE, Greaves MW (1993) Cutaneous extravascular necrotizing granuloma (Churg-Strauss) as a paraneoplastic manifestation of nonHodgkin's B-cell lymphoma. J R Soc Med 86: 549-550.

17. Vougiouklakis T, Mitselou A, Agnantis NJ (2004) Churg-Strauss syndrome (allergic granulomatous angiitis) associated with $\mathrm{T}$ lymphoblastic lymphoma. In Vivo 18: 477-480.

18. Correia Cda C, Teixeira HM, Melo RV (2011) Vasculitic neuropathy presenting as Churg-Strauss paraneoplastic syndrome: a rare association. Arq Neuropsiquiatr 69: 994-995.
19. Fruguglietti ME, Napoli L, Sciacco M, Ripolone M, Serafini M, et al. (2009) Severe acute multineuropathy in Churg-Strauss syndrome in a patient with a history of melanoma. Clin Neuropathol 28: 125-128.

20. Maul LV, Weichenthal M, Kähler KC, Hauschild A (2016) Successful antiPD-1 antibody treatment in a metastatic melanoma patient with known severe autoimmune disease. J immunother 39:188-190.

21. Liu T, Cai B, Feng R (2012) Churg-Strauss syndrome presented as paraneoplastic syndrome with thymic neuroendocrine carcinoma: a case report. Reumatol Int 32: 3683-3685.

22. Chemouny JM, Pagnoux C, Caudwell V, Karras A, Borie R, et al. (2014) ANCA-associated diseases and lung carcinomas: a five-case series. Clin Nephrol 81: 132-137.

23. Kabaria R, Klaassen Z, Terris MK (2016) Renal cell carcinoma: links and risks. Int J Nephrol Renovasc Dis 9: 45-52.

24. Low G, Huang G, Fu W, Moloo Z, Girgis S (2016) Review of renal cell carcinoma and its common subtypes in radiology. World J Radiol 8: 484-500.

25. Kryvenko ON, Jorda M, Argani P, Epstein JI (2014) Diagnostic approach to eosinophilic renal neoplasms. Arch Pathol Lab Med 138: 1531-1541.

26. Othmane Y, Mounir L, Tarik K, Khalid E, Abdellatif K, et al. (2015) Chromophobe renal cell carcinoma: about four cases and review of the literature. Pan Afr Med J 22: 123.

27. Benoit Corven C, Khalaf A, Courville P, Sibert L, Gobet F, et al. (2003) Renal chromophobe cell carcinoma and paraneoplastic linear IgA bullous dermatosis. J Urol 169: 270-271.

28. Wei YB, Yan B, Yin Z, Yang JR (2014) Chromophobe renal cell carcinoma associated with eosinophilia: A report of three cases. Exp Ther Med 8: 91-94. 